ks. Leszek Szewczyk ${ }^{1}$

0000-0003-0424-3205

Uniwersytet Śląski w Katowicach

\title{
Głosiciel z Duchem. Rola Ducha Świętego w kaznodziejstwie według Evangelii gaudium
}

Święty Augustyn skierował do głosicieli słowa Bożego następującą zachętę: „Kto pragnie opanować sztukę uczenia innych i doskonalić kunszt wymowy odpowiedniej mężowi kościelnemu, niech się wprawdzie uczy wszystkiego, co potrzebne, ale w chwili samego wygłaszania niech pamięta, że w głębi serca trzeba zastosować się do tego co rzekł Pan: «Nie martwcie się o to, jak, ani co, macie mówić, bo w owym czasie będzie wam poddane, co macie mówić. Bo nie wy będziecie mówić, lecz Duch Ojca waszego mówić będzie w was» (Mt 10,19). Jeśli Duch Święty przemawia przez tych, którzy dla Chrystusa byli wydawani prześladowaniom, dlaczegożby nie mówił przez tych, którzy ludziom spragnionym wiedzy głoszą Chrystusa"2.

1 Ks. dr hab. Leszek Szewczyk - prezbiter archidiecezji katowickiej, doktor habilitowany nauk teologicznych w zakresie homiletyki, profesor w Katedrze Teologii Pastoralnej, Liturgiki, Homiletyki i Katechetyki Wydziału Teologicznego Uniwersytetu Śląskiego w Katowicach, Kierownik Studiów Doktoranckich WTL UŚ, dyplomowany logopeda. Adres do korespondencji: ul. Starokościelna 3, 41-400 Mysłowice. E-mail: leszek.szewczyk@us.edu.pl.

2 Augustyn, O nauce chrześcijańskiej, Warszawa 1979, s. 115. 
Przekonanie o szczególnej roli Ducha Świętego w dziele przepowiadania słowa Bożego uwidoczniło się bardzo wyraźnie w czasie odnowy kaznodziejstwa w XX wieku. Powrócono do wypowiedzi Pisma Świętego i nauki ojców Kościoła stwierdzających, że pierwszorzędnym podmiotem kościelnego przepowiadania słowa Bożego jest Bóg mówiący przez Jezusa Chrystusa w Duchu Świętym. W głoszeniu słowa Bożego szczególna rola przypada Duchowi Świętemu, na co wskazuje papież Paweł VI w adhortacji apostolskiej Evangelii nuntiandi: „Nigdy nie może zaistnieć przepowiadanie bez pomocy Ducha Świętego [...]. Techniczne środki ewangelizacji są dobre, ale choćby były absolutnie doskonałe, nie zastąpią cichego tchnienia Ducha. Również najlepsze przygotowanie głosiciela nie da wyniku bez Niego. I żadna wymowa nie zdoła poruszyć człowieka bez Jego tchnienia" (EN 75). Na szczególną rolę Ducha Świętego w kaznodziejstwie wskazuje również papież Franciszek w adhortacji apostolskiej o głoszeniu Ewangelii we współczesnym świecie Evangelii gaudium z 2013 roku. Papież Franciszek w analizowanej adhortacji często przywołuje nauczanie swoich poprzedników (18 razy cytuje nauczanie Benedykta XVI, 25 razy odwołuje się do nauczania Pawła VI i aż 51 razy do Jana Pawła II). $Z$ racji poruszanej problematyki 13 razy odwołuje się do adhortacji apostolskiej o ewangelizacji w świecie współczesnym Evangelii nuntiandi Pawła VI i 10 razy do dokumentu Konferencji Episkopatów Ameryki Łacińskiej i Karaibów z Aparecidy.

Tomasz Jaklewicz na łamach „Gościa Niedzielnego” podzielił się następującą refleksją: „Irytuje mnie ciągłe podkreślanie, że papież Franciszek dokonuje przewrotu w Kościele. Ale czytając adhortację apostolską Evangelii gaudium przyznaję, że czuje się w niej niesamowitą siłę. To jest potężny powiew Ducha Świętego, tak, to jest wezwanie do duchowej rewolucji w samym Kościele [...]. Otrzymujemy tekst autorski natchnionego misjonarza, duszpasterza kochającego ubogich, domagającego się dla nich sprawiedliwości. To jest prorockie przynaglenie

3 Paweł VI, Adhortacja apostolska „Evangelii nuntiandi” o ewangelizacji w świecie współczesnym (dalej: EN), Rzym 1975, https://opoka.org.pl/biblioteka/W/WP/pawel_vi/adhortacje/ evangelii_nuntiandi.html (15.09.2018). 
duchownych i świeckich, aby się obudzili i żyli w stanie permanentnej misji [...]. Do tego tekstu będziemy jeszcze wracać. Jest w nim wielki ogień, czujemy zapał i entuzjazm Piotra naszych czasów"4.

Z całą pewnością warto wracać do tekstu adhortacji i jej treści, które dotyczą Ducha Świętego. Tym bardziej, że zagadnienia pneumatologiczne są w niewystarczającym stopniu obecne zarówno w polskiej teorii homiletycznej ${ }^{5}$, jak i praktyce kaznodziejskiej ${ }^{6}$. W niniejszym opracowaniu podjęte zostaną zagadnienia treści pneumatologicznych $\mathrm{w}$ przepowiadaniu kaznodziejskim, powołania do słuchania ludzi i głoszenia słowa Bożego, roli Ducha Świętego w przygotowaniu do głoszenia słowa Bożego, duchowości głosiciela słowa Bożego. Wskazane również zostaną niebezpieczeństwa zagrażające współczesnym kaznodziejom. Podstawowym źródłem opracowania jest adhortacja apostolska Evangelii gaudium, z której powyższe zagadnienia zostaną wydobyte i przeanalizowane.

4 T. Jaklewicz, Misyjna rewolucja papieża, https://www.gosc.pl/doc/1793999.Misyjna-rewolucja-papieza (20.09.2018).

5 W ostatnim dwudziestoleciu zagadnienie roli Ducha Świętego w kaznodziejstwie podejmowali między innymi: S. Budzik, Jak mówić o Duchu Świętym, w: Prawdy wiary w przepowiadaniu, red. W. Przyczyna, Kraków 2002, s. 63-74; S. Dyk, Wydarzenia pentekostalne (Dz 2,1-47) w polskim przepowiadaniu posoborowym. Studium egzegetyczno-homiletyczne, Lublin 1998; S. Dyk, Głoszenie kerygmatu o zesłaniu Ducha Świętego (Dz 2,1-11) w polskim przepowiadaniu posoborowym, „Roczniki Teologiczne” 51 (2004) nr 8, s. 167-187; S. Dyk, Duch - Słowo - Kościót. Biblijny model ewangelizacji, Lublin 2007; S. Dyk, Homilia miejscem obecności i działania Ducha Świętego, „Zeszyty Naukowe KUL” 50 (2007) nr 2, s. 33-47; S. Dyk, Duch Święty jako podmiot i treść przepowiadania homilijnego, „Studia Pastoralne” 4 (2008), s. 148-170; S. Dyk, Przestrzeń dla Ducha Świętego w kaznodziejstwie, „Pastores” 65 (2014) nr 4, s. 36-43; H. Sławiński, Homiletyka w dobie nowej ewangelizacji, „Acta. Facultatis Theologicae Universitatis Comenianae Bratislaviensis” 8 (2011) nr 2, s. 12-26; J. Twardy, Pneumatologiczny aspekt głoszenia słowa Bożego, w: Z Duchem Świętym $w$ trzecie tysiąclecie, red. J. Budniak, M. J. Uglorz, Cieszyn 2002, s. 137-149; J. Twardy, Kaznodziejskie nauczanie o Duchu Świętym w roku liturgicznym, „Przegląd Homiletyczny” 10 (2006), s. 71-83; W. Turowski, Miejsce głoszenia kerygmatu we wspólnocie parafialnej, „Studia nad Rodziną" 16 (2012) nr 1-2, s. 211-230; W. Turowski, Duch Święty a głosiciel słowa Bożego, „Studia Teologiczne. Białystok-Drohiczyn-Łomża” 35 (2017), s. 163-185.

6 W kwestionariuszu ankiety na pytanie o częstotliwość głoszenia prawd wiary kaznodzieje wskazali, że zagadnienie Ducha Świętego pojawia się rzadko (61,7\% ankietowanych), a niekiedy wcale (1,2\%). L. Szewczyk, Odnowa przepowiadania słowa Bożego w (archi)diecezji katowickiej po Soborze Watykańskim II. Studium homiletyczne, Katowice 2009, s. 221. 


\section{Duch Święty treścią przepowiadania}

Zdaniem Stanisława Dyka, najlepszym sposobem nauczania o Duchu Świętym jest ukazywanie Jego działania w Chrystusie, w Kościele, w świecie i w poszczególnym człowieku. Właśnie takie spojrzenie na Ducha Świętego odnaleźć można na kartach Pisma Świętego. Również w przepowiadaniu homilijnym trzeba „ukazywać owoce działania Ducha: nawrócenie, wiarę, miłość, świadectwo, braterską służbę, radość, zmartwychwstanie. Dopiero ze skutków poznajemy, kim jest Duch Święty i jak bardzo potrzebne jest otwarcie się na Jego działanie"7. Już na etapie przygotowania homilii należy pamiętać o prawdach dotyczących działalności Ducha Świętego, który objawia nam Ojca, objawia Jezusa oraz objawia siebie samego ${ }^{8}$.

W adhortacji apostolskiej Evangelii gaudium ${ }^{9}$ znajduje się zachęta do głoszenia prawdy o posłanym przez Ojca i Syna Duchu Świętym, który przemienia ludzkie serca i czyni je zdolnymi do wejścia w doskonałą komunię Przenajświętszej Trójcy, gdzie wszystko znajduje swoją jedność. To Duch Święty, będąc harmonią oraz więzią miłości między Ojcem i Synem, tworzy komunię i harmonię Ludu Bożego. On też w Kościele rozbudza bogactwo darów i buduje jedność (EG 117). Papież Franciszek przypomina prawdę o tym, że uświęcająca moc Ducha Świętego działa we wszystkich ochrzczonych oraz każdego z nich pobudza do ewangelizowania. To Duch Święty prowadzi wierzących ku prawdzie, pociąga do zbawienia oraz zapewnia chrześcijanom zespolenie z rzeczywistością Bożą (EG 119).

Głosicielom słowa Bożego powinna towarzyszyć świadomość, że wiara nie jest wynikiem perfekcyjnego przekazywania informacji, lecz twórczej mocy Ducha Świętego. W treści kaznodziejskiego przepowiadania o Duchu Świętym nie może również zabraknąć przesłania o udzielanych przez Niego darach, charyzmatach. Dary Ducha Świętego są włączone

S. Dyk, Duch Święty jako podmiot..., dz. cyt., s. 165.

8 W. Turowski, Duch Święty a głosiciel..., dz. cyt., s. 165-167.

9 Franciszek, Adhortacja apostolska „Evangelii gaudium” o głoszeniu Ewangelii we współczesnym świecie (2013), Kraków 2013 [dalej: EG]. 
w Ciało Kościoła, skierowane ku centrum, którym jest Chrystus. Zaś widocznym znakiem autentyczności jakiegoś charyzmatu jest jego eklezjalność, zdolność do włączenia się w życie Kościoła (EG 130). Choć doświadczenia podziałów między osobami i wspólnotami są dokuczliwe, to Duch Święty może ze wszystkiego wyprowadzić dobro. Jedynie On „może wzbudzić różnorodność, wielość, wielorakość i jednocześnie urzeczywistniać jedność (EG 131). Adhortacja przypomina prawdę o fundamentalnej roli pierwszego przepowiadania, „kerygmy”, która zajmuje centralne miejsce w całej działalności ewangelizacyjnej oraz w każdej próbie odnowy Kościoła. Kerygma ta jest trynitarna: „Jest ogniem Ducha udzielającego się pod postacią języków i sprawiającego, że wierzymy w Jezusa Chrystusa, który przez swą śmierć i zmartwychwstanie objawia nam i komunikuje nieskończone miłosierdzie Ojca" (EG 164).

Zdaniem papieża Franciszka, wszelkie przepowiadanie kaznodziejskie, także podejmujące zagadnienie Ducha Świętego, powinno przypominać rozmowę matki (Kościoła) z dzieckiem. Dobra matka wsłuchuje się w troski dziecka i od niego się uczy. Ich wzajemna miłość wpływa na wartość dialogu i pozwala korygować swoje postawy oraz doceniać rzeczy dobre. Duch Święty, który inspiruje Ewangelię i działa w Ludzie Bożym, wskazuje głoszącemu słowo Boże, że również w homilii „powinno się wsłuchiwać w wiarę słuchaczy” oraz „wiedzieć, co należy mówić, jak i znaleźć właściwy sposób, by to powiedzieć” (EG 139). Papież Franciszek przestrzega głosicieli słowa Bożego przed używaniem specjalistycznego języka teologicznego, nieznanego ich słuchaczom (EG 158). Zwraca uwagę, że o wierze powinno się opowiadać w kluczu „kultury ojczystej” „macierzyńskiej”, w kluczu ojczystego - „macierzyńskiego” dialektu. Temu zaś powinna sprzyjać postawa głosiciela słowa Bożego otwartego na dialog, serdecznego, bliskiego, cechującego się ciepłym tonem głosu, spokojnym stylem zdań i radością gestów (EG 139, 140).

\section{Powołanie do słuchania ludzi i głoszenia słowa Bożego}

Współczesny kaznodzieja powinien posiadać zdolność uważnego słuchania drugiego człowieka. Kapłani „muszą słuchać współczesnej 
ludzkości, bliźniego, członka swojej parafii, człowieka, za którego są w pewnym sensie odpowiedzialni” ${ }^{10}$. Według papieża Franciszka, zadaniem głosiciela słowa Bożego jest, oprócz wnikliwego słuchania Boga, uważne słuchanie drugiego człowieka. Kaznodzieja jest bowiem „człowiekiem kontemplującym Słowo, a także kontemplującym lud" (EG 154). Pozwala to powiązać przesłanie danego tekstu biblijnego z doświadczeniem współczesnego człowieka. Słuchanie pełne szacunku i zdolne do współczucia pomaga odnaleźć drogi rozwoju, rozbudzić pragnienie ideału chrześcijańskiego i odpowiedzieć w pełni na Bożą miłość (EG 171). Papież Franciszek w Evangelii gaudium szeroko omawia zagadnienie powołania do głoszenia słowa Bożego. To Bóg powołuje głosicieli Jego słowa i pobudza mocą swego Ducha. Do Niego należy inicjatywa, bowiem On „pierwszy nas umiłował” (1 J 4, 19) i ,daje wzrost” (1 Kor 3, 7). On też powołanego inspiruje, prowokuje, kieruje nim i „towarzyszy na tysiąc sposobów" (EG 12). Wielkość głoszonego orędzia, przez swoje bogactwo i głębię, przerasta możliwości człowieka. To Duch Święty przychodzi z pomocą głoszącemu i podsuwa myśl i słowo odpowiednie do okoliczności, w których przemawia (EG 128). Duch Święty wnosi światło pośród mroków, bowiem gdzie „wzmógł się grzech, tam jeszcze obficiej rozlała się łaska” (Rz 5, 20). „Nasza wiara wezwana jest, by dostrzec wino, w które może być przemieniona woda, i odkryć ziarno rosnące pośród kąkolu" (EG 84).

Przejawem miłości kaznodziei do ludzi jest także modlitwa za słuchaczy, za adresatów głoszonego słowa, za ewangelizowanych. Modlitwa za lud służy głosicielowi, wzmaga jego gorliwość, czyni jego serce bardziej hojnym, otwartym, gotowym dzielić życie z innymi (EG 282).

10 Benedykt XVI, Z wielką miłością do Chrystusa i Kościoła, „L'Osservatore Romano”, wyd. pol., 26 (2005) nr 7-8, s. 14-15. 


\section{Zaufanie Duchowi Świętemu początkiem przygotowania do głoszenia słowa Bożego}

Skuteczność przepowiadania słowa Bożego w dużej mierze zależy od kaznodziei, od jego kompetencji, gorliwości, wiedzy. Słabo przygotowana wypowiedź kaznodziei, niedbale wygłoszona, może zniechęcić człowieka do słuchania słowa Bożego ${ }^{11}$. Adhortacja apostolska Evangelii gaudium podkreśla znaczenie przygotowania do przepowiadania słowa Bożego, które jest tak ważnym zadaniem, „że należy poświęcić mu dłuższy czas studium, modlitwy, refleksji i kreatywności duszpasterskiej". Papież Franciszek zachęca kaznodziejów do poświęcenia na przygotowanie homilii wystarczająco długiego czasu osobistego i wspólnotowego, ,nawet gdyby trzeba było przeznaczyć mniej czasu na inne zadania, choćby i ważne" (EG 145).

Przygotowanie do głoszenia słowa Bożego zakłada najpierw zaufanie Duchowi Świętemu. To aktywne i kreatywne zaufanie „pociąga za sobą ofiarowanie się jako narzędzie (por. Rz 12, 1), ze wszystkimi swoimi zdolnościami, aby Bóg mógł się nimi posłużyć. Kaznodzieja, który się nie przygotowuje, nie jest «duchowy», jest nieuczciwy i nieodpowiedzialny wobec otrzymanych darów" (EG 145).

Kolejnym etapem przygotowania do głoszenia słowa Bożego, zdaniem papieża Franciszka, jest „poświęcenie całej uwagi tekstowi biblijnemu, który powinien stanowić podstawę przepowiadania". Postawa pokornej czci wobec Słowa, studiowanie go z najwyższą uwagą pozwala głoszącemu uniknąć niebezpieczeństwa manipulowania tekstem świętym. A cierpliwość, wolność od wszelkiego niepokoju, poświęcenie odpowiedniego czasu i zainteresowanie pozwolą właściwie zinterpretować tekst biblijny (EG 146).

W zaproponowanej przez papieża Franciszka metodzie przygotowania homilii należy następnie odkryć główne przesłanie tekstu biblijnego i jego struktury (EG 147). We właściwym zrozumieniu sensu centralnego przesłania danego tekstu pomocne jest porównanie go z nauczaniem

11 G. Siwek, Przepowiadanie słowa Bożego, w: Teologia pastoralna, t. 2, red. R. Kamiński, Lublin 2002, s. 142. 
całej Biblii, przekazanym przez Kościół. Rozwlekłe i nieskuteczne przepowiadanie, zdaniem papieża, wynika z braku zdolności przekazania mocy proklamowanego tekstu (EG 147).

Następny etap właściwego przygotowania przepowiadanego słowa polega na pogłębieniu osobistej zażyłości głosiciela ze słowem Bożym do tego stopnia, żeby „przeniknęło ono do głębi jego myśli i uczucia i zrodziło w nim nową mentalność" (EG 149). Głoszenie słowa Bożego powinno być poprzedzone przyzwoleniem na gotowość zranienia przez Słowo, które zrani innych, ponieważ jest to Słowo żywe i skuteczne, „które jak miecz obosieczny "przenika aż do rozdzielenia duszy i ducha, stawów i szpiku, zdolne osądzić pragnienia i myśli serca» (Hbr 4, 12)” (EG 150). Kaznodzieja powinien słuchać Słowa w postawie szczerego otwarcia, pozwolić, aby Słowo to dotknęło jego życia i zakwestionowało je. Słowo to ma zachęcać i mobilizować (EG 151).

Papież Franciszek wskazuje także konkretne pomoce służące dobremu przygotowaniu do pełnienia posługi słowa. Przygotowaniu temu służą: czytanie duchowe (lectio divina), uważne słuchanie współczesnego człowieka i poznawanie jego życiowych problemów oraz wykorzystywanie narzędzi pedagogicznych w posłudze słowa (troska o właściwy sposób przepowiadania, posługiwanie obrazami, dostosowanie do języka słuchaczy, jedność tematyczna, jasny porządek i logika wywodu oraz stosowanie pozytywnego języka) ${ }^{12}$. Właściwe przygotowanie do głoszenia słowa Bożego polega na ewangelicznym rozeznaniu, „w którym człowiek w świetle Ducha - stara się rozpoznać «Boże wezwanie, rozbrzmiewające w określonej sytuacji historycznej. Również w niej i przez nią Bóg wzywa wierzących»" (EG 154). Przez słowa kaznodziei i przez działanie Ducha Świętego słowo ożywa na nowo. To dzięki asystencji Ducha Świętego udzielonej głosicielom Bożego orędzia „słowo Boże wychodzi z kenozy”13.

12 Por. EG 152-159.

13 H. Sławiński, Liturgiczne przepowiadanie słowa Bożego jako jedno z naczelnych zadań postugi kapłańskiej, „Kieleckie Studia Teologiczne” 1 (2002), s. 164. 


\section{Duchowość głosiciela słowa Bożego}

Piąty rozdział Evangelii gaudium papież Franciszek opatrzył tytułem Ewangelizatorzy $z$ duchem. W dwudziestu pięciu kolejnych punktach (EG 259-283) ukazuje duchowość głoszących słowo Boże. Duchowość głosicieli słowa Bożego charakteryzuje się otwarciem na działanie Ducha Świętego (EG 259). Otwarcie to sprawia, że Duch Święty będzie działał w głosicielu Ewangelii, ponieważ ,podsuwa mu słowa, jakie tylko On jeden może poddać” (EG 151), a sam głosiciel otrzyma siłę do „głoszenia nowości Ewangelii śmiało, głośno, w każdym czasie i miejscu, także pod prąd” (EG 259). Kaznodzieja, w sercu którego „żarzy się ogień Ducha” odnajduje właściwą motywację do „gorliwej, radosnej, ofiarnej, śmiałej” ewangelizacji. To Duch Święty jest duszą ewangelizującego Kościoła (EG 261).

Ewangelizatorzy powinni być ludźmi modlitwy, bowiem „bez dłuższych chwil adoracji, modlitewnego spotkania ze Słowem, zadania łatwo pozbawione zostają sensu, my zaś czujemy się osłabieni z powodu zmęczenia i trudności, a zapał gaśnie" (EG 262). od kaznodziei wymaga się obcowania ze słowem Boga, kontemplacji tego słowa, która umożliwia czytanie Ewangelii nie tylko umysłem, ale i sercem, oraz medytacji przenikającej umysł i serce głosiciela, a także pozwalającej zakosztować słowa Bożego w życiu (EG 264).

Kolejną postawą, wymaganą od głosicieli słowa Bożego, jest więź z Chrystusem. Kaznodzieja, chcący skutecznie pełnić swoje posłannictwo, musi trwać w zjednoczeniu z Chrystusem, który „kroczy z nim, rozmawia z nim, oddycha z nim, pracuje z nim" (EG 266). Współczesny głosiciel słowa powinien cechować się umiłowaniem ludu, miłością do swoich słuchaczy. Przez kaznodzieję Bóg zbliża się do człowieka. Bóg powołuje głosicieli słowa z ludu i do niego posyła, dlatego bez przynależności do Boga nie można zrozumieć kaznodziejskiej tożsamości (EG 268). Dla głosiciela słowa Bożego miejscem rzeczywistego i intensywnego doświadczenia Ducha jest homilia, która jest stałym źródłem odnowy i wzrastania (EG 135). Postawa głosiciela słowa Bożego powinna cechować się otwartością, bliskością serca, miłością i pragnieniem dawania świadectwa (EG 42). Odkrycie działania Ducha Świętego pozwala wyjść 
z ograniczonych schematów duchowych i podejmować dzieła służące dobru bliźniego (EG 272). Głębokie i nieustanne zaufanie do Ducha Świętego jest niezbędne do podtrzymania żywego zapału misyjnego. To Duch Święty leczy wszystko, co przyczynia się do osłabienia zapału misyjnego. Kaznodziei zaś powinno towarzyszyć przekonanie, że Duch Święty, który oświeca, prowadzi i kieruje jego słowem i życiem, jest jednocześnie źródłem autentycznej wolności (EG 280). Od współczesnych głosicieli wymaga się osobistej świętości oraz otwartości na działanie Ducha Świętego. Wzorem takiej postawy są apostołowie, którzy głosili z entuzjazmem Chrystusa, a ich słowa miały Bożą moc, ponieważ otworzyli się na działanie Ducha Świętego, pozwolili, by On ich uświęcił ${ }^{14}$.

\section{Zagrożenia stojące przed głosicielem słowa Bożego}

Głosicielom słowa Bożego zagrażają również konkretne niebezpieczeństwa. Jeżeli kaznodzieja „nie zatrzyma się na słuchaniu Słowa w postawie szczerego otwarcia, jeśli nie pozwoli, by dotknęło ono jego życia, by je zakwestionowało, by go zachęcało, by go zmobilizowało, jeśli nie poświęca czasu, by modlić się Słowem, wtedy stanie się fałszywym prorokiem, oszustem lub pustym szarlatanem" (EG 151). Równie duże niebezpieczeństwo czyha na kaznodzieję, który traci entuzjazm, siłę i pasję. Głosiciel słowa Bożego, który nie jest przekonany do głoszonego słowa, nie jest entuzjastą, nie jest zakochany w tym, co głosi, nie będzie w stanie nikogo przekonać (EG 266). Poważnym zagrożeniem dla kaznodziei jest osłabienie jego duchowości, które przejawia się między innymi w osłabieniu lub zaniechaniu życia modlitewnego.

Współczesnemu kaznodziei, któremu często towarzyszą rozliczne wymogi troski duszpasterskiej i poczucie osobistej nieudolności, zagraża również postawa zniechęcenia. Postawa ta często połączona jest z acedią, czyli duchowym lenistwem. Zdaniem papieża Franciszka, wyrażonym w adhortacji Evangelii gaudium, duszpasterska acedia może mieć różne przyczyny: snucie planów nie do zrealizowania; brak akceptacji dla

14 W. Turowski, Miejsce głoszenia kerygmatu..., dz. cyt., s. 222. 
dokonującej się trudnej ewolucji; przywiązanie do - podtrzymywanych próżnością - projektów lub snów o sukcesie; brak umiejętności czekania. Może również dojść do chęci całkowitego panowania nad rytmem życia oraz do utraty realnego kontaktu z innymi osobami w odpersonalizowanym duszpasterstwie. Duszpasterstwo takie prowadzi do zwracania większej uwagi nie na ludzi, lecz na samą organizację działalności. Większy entuzjazm wywołuje „konstruowanie planu drogi” niż sama „droga”, którą trzeba przejść (EG 82).

Konkretną pomocą, ułatwiającą unikanie powyższych niebezpieczeństw, jest modlitwa. Warunkuje ona skuteczność głoszonego słowa, gdyż bez niej każde działanie człowieka jest narażone na duże ryzyko. Grozi mu, że działanie to ,pozostanie puste, a orędzie będzie pozbawione duszy" (EG 259). Modlitwa przemienia głosiciela słowa Bożego i rodzi w nim „nową mentalność” (EG 149).

Zdaniem Josha Geninga, w kościelnym głoszeniu słowa Bożego często jeszcze dominuje przepowiadanie charakterystyczne dla epoki modernizmu, a było ono z konieczności bardziej dydaktyczne niż kerygmatyczne ${ }^{15}$. Kaznodziejstwo takie, chcąc dotrzeć do ludzi o mentalności modernistycznej, oderwane jest od życia i reprezentuje jedno z dwóch niewłaściwych sposobów wygłaszania homilii. Pierwszym z nich jest tzw. naukowe podejście do wygłaszania homilii, drugie - Gening nazywa głoszeniem słowa „pełnym Ducha”. W pierwszym przypadku duszpasterz wyrywa perykopę przeznaczoną do odczytania na dany dzień z całości orędzia biblijnego i stosuje do jej objaśnienia przede wszystkim narzędzia historyczne, filologiczne i literackie. Konsekwencją jest mowa oderwana od życia słuchaczy, z dużą ilością teologicznych twierdzeń, abstrakcyjnych rozważań doktrynalnych, angażująca umysł, a nie serce słuchaczy. Kaznodziejstwo „pełne Ducha” skutkuje w dwojaki sposób. Z jednej strony duszpasterz uważa, że Duch Święty go poprowadzi i polega na własnej, często utożsamianej z Duchem Świętym, zdolności oczarowania słuchaczy i skupia uwagę bardziej na sobie niż na osobie Jezusa Chrystusa. Z drugiej, przeciwnej strony, dominuje tendencja do głoszenia słowa doskonałego pod względem teologicznym, ale bez dbałości

15 J. Genig, Kaznodziejstwo w postmodernistycznym świecie, „Pastores” 64 (2014) nr 3, s. 44. 
o atrakcyjność i stosowanie zasad retoryki. To powoduje zamknięcie się słuchacza na głoszone słowo ${ }^{16}$. Tymczasem działanie Ducha Świętego powinno „umacniać nadzieję kaznodziei oraz motywować go do starannego opracowywania mowy, do wykonywania swej posługi z pasją, do stawania na wysokości powierzonego mu Słowa"17.

Adhortacja apostolska o głoszeniu Ewangelii we współczesnym świecie Evangelii gaudium jest tekstem, do którego warto wracać. Wyraźnie można dostrzec w nim ogień, zapał i entuzjazm papieża Franciszka. Przesłanie athortacji zawiera również wyraźną sugestię dla współczesnych głosicieli słowa Bożego, jak ten zapał i entuzjazm wzbudzać w praktyce kaznodziejskiej.

16 J. Genig, Kaznodziejstwo w postmodernistycznym świecie, „Pastores” 64 (2014) nr 3, s. 50.

17 C. Biscontin, Kwalifikacje kaznodziei, „Przegląd Homiletyczny” 8 (2004), s. 15. 


\section{Summary}

\section{Głosiciel z Duchem. Rola Ducha Świętego w kaznodziejstwie według Evangelii gaudium}

Papież Franciszek w adhortacji apostolskiej Evangelii gaudium o głoszeniu Ewangelii we współczesnym świecie z 2013 roku podejmuje wiele zagadnień dotyczących roli Ducha Świętego w praktyce kaznodziejskiej. W opracowaniu zostały podjęte zagadnienia dotyczącekwestii pneumatologicznych w przepowiadaniu kaznodziejskim, powołania do słuchania ludzi i głoszenia słowa Bożego, roli Ducha Świętego w przygotowaniu do głoszenia słowa Bożego, duchowości głosiciela słowa Bożego. Wskazane również zostały niebezpieczeństwa zagrażające współczesnym kaznodziejom. Podstawowym źródłem opracowania jest przesłanie Evangeliigaudium, z której powyższe zagadnienie zostały wydobyte i przeanalizowane.

Słowa kluczowe: Duch Święty, Evangelii gaudium, głosiciel słowa Bożego

\section{A Preacher with the Spirit. The Role of the Holy Spirit in Preaching according to Evangelii gaudium}

Pope Francis in his apostolic exhortation on preaching the Good News in the contemporary world Evangelii gaudium published in 2013 discusses numerous issues related to the role of the Holy Spirit in the preaching practice. The study includes the topic of pneumatological content in preaching, the call to listen to people and preaching the word of God, the role of the Holy Spirit in preparation for preaching the word of God, spirituality of a preacher of the word of God. Also, it focuses on dangers faced by contemporary preachers. The basic source of the study is the apostolic exhortation Evangelii gaudium which the issues mentioned above have been derived from and analyzed.

Key words: Holy Spirit, Evangelii gaudium, a preacher of the word of God

\section{Bibliografia}

Augustyn, O nauce chrześcijańskiej, Warszawa 1979.

Benedykt XVI, Z wielka miłościa do Chrystusa i Kościoła, „L'Osservatore Romano”, wyd. pol., 26 (2005) nr 7-8, s. 14-15.

Biscontin C., Kwalifikacje kaznodziei, „Przegląd Homiletyczny” 8 (2004), s. 7-16.

Dyk S., Duch Święty jako podmiot i treść przepowiadania homilijnego, „Studia Pastoralne" 4 (2008), s. 148-170. 
Franciszek, Adhortacja apostolska „Evangelii gaudium” o głoszeniu Ewangelii we wspótczesnym świecie (2013), Kraków 2013.

Genig J., Kaznodziejstwo w postmodernistycznym świecie, „Pastores” 64 (2014) nr 3, s. $42-50$.

Jaklewicz T., Misyjna rewolucja papieża, https://www.gosc.pl/doc/1793999.Misyjna-rewolucja-papieza (20.09.2018).

Siwek G, Przepowiadanie słowa Bożego, w: Teologia pastoralna, t. 2, red. R. Kamiński, Lublin 2002, s. 131-179.

Sławiński H., Liturgiczne przepowiadanie słowa Bożego jako jedno z naczelnych zadań posługi kapłańskiej, „Kieleckie Studia Teologiczne” 1 (2002), s. 158-171.

Szewczyk L., Odnowa przepowiadania słowa Bożego w (archi)diecezji katowickiej po Soborze Watykańskim II. Studium homiletyczne, Katowice 2009.

Turowski W, Duch Święty a głosiciel słowa Bożego, „Studia Teologiczne. BiałystokDrohiczyn-Łomża" 35 (2017), s. 163-185.

Turowski W., Miejsce głoszenia kerygmatu we wspólnocie parafialnej, „Studia nad Rodziną" 16 (2012) nr 1-2, s. 211-230. 